\title{
Successful reproduction of Trachemys scripta in the Altrhein of Kehl (Germany) and simultaneous increase in population estimate
}

\author{
CARSTEN SCHRADIN ${ }^{1,2}$ \\ ${ }^{1}$ Université de Strasbourg, CNRS, IPHC UMR 7178, F-67000 Strasbourg, France \\ ${ }^{2}$ School of Animal, Plant and Environmental Sciences, University of the Witwatersrand, South Africa \\ Author e-mail: carsten.schradin@iphc.cnrs.fr
}

\begin{abstract}
The European Union categorises pond sliders (Trachemys scripta) as invasive species for which all member countries have to develop an action plan. To date it has been assumed that the climate in Germany is too cold for T. scripta to survive or reproduce. Data collected annually from 2016 to 2020 show that the population of exotic pond turtles in an oxbow lake (Althrein of Kehl, Germany) did not decrease but increased. In addition, the diversity of species released was found to be high, five other exotic species in addition to T. scripta were observed. The population of T. scripta in particular appears to be increasing, with no indication of high mortality due to cold winters and apparently regular successful reproduction (hatchlings observed in four out of five study years and caught in two years). The current action plan in Germany for T. scripta will have to change if potential negative impacts are to be avoided. Other west and central European countries might also have to modify their action plans accordingly.
\end{abstract}

\section{INTRODUCTION}

Invasive species are threatening native biodiversity worldwide. Neobiota are alien species that establish themselves outside their natural distribution range due to human action, i.e. they reproduce successfully in the areas in which they have been released and they maintain their population (Geiger \& Waitzmann 1996; Wilson et al., 2009). They are regarded as being invasive if they have the capacity to spread into new areas and at the same time cause harm to the native fauna and/or flora by predation and/or competition (Lowe et al., 2000; Wilson et al., 2009).

Of the world`s 100 worst invasive alien species, only two species are reptiles, the brown tree snake (Boiga irregularis) from Australia and the red-eared slider (Trachemys scripta) from North America (Lowe et al., 2000). Compared to invertebrates ( 26 of the 100 worst invasive species) and small mammals (10 of the 100 the worst invasive species), reptiles grow, mature, and reproduce slowly, which can be one reason why so few reptiles are invasive. However, a slow life history also makes it more difficult to monitor and predict the long-term consequences of an introduced alien species, i.e. whether it will establish itself and become invasive or not. From an ecological point of view it is not important whether an invasion takes a few years or 100 years, as the long-term consequences on the native flora and fauna would still be deleterious. The potentially invasive $T$. scripta has been released worldwide, including central and south America (Böhm, 2013), Asia (Mo, 2019), and Europe (Standfuss et al., 2016). While the slow life history of the species should theoretically allow a timely reaction by authorities, unfortunately the opposite has occurred. Small neobiota populations are often ignored and long-term monitoring programmes are only established many years after the population has grown to a size that makes population control difficult (Sancho \& Lacomba, 2016). While T. scripta has become invasive in areas with tropical, sub-tropical, and Mediterranean climates (Lowe et al., 2000; Foglini \& Salvi , 2017), the consequences in areas with temperate climates are unclear (Cadi et al., 2004; Prevot et al., 2007; Kopecký, Kalous \& Patoka, 2013; Standfuss et al., 2016).

In 2014, the European Union published Regulation (EU) No $1143 / 2014$, declaring an action plan to prohibit the import, breeding and release of invasive species (European Parliament, 2014), including T. scripta (European Commission, 2016). A regulation is a legal act of the European Union that becomes immediately enforceable as law in all member states. Thus, this regulation forces all member states to take actions to avoid the spread of the declared invasive species. As environmental conditions differ between members states, the individual states are allowed to respond differently. In Germany, the proposed actions against T. scripta are to increase public awareness, allowing non-commercial transfer of individuals that are already kept in captivity (to avoid these individuals being released into the wild), while the removal of individuals from wild habitats is not considered to be feasible as it is thought to be both ineffective and very costly (StA "Arten- und Biotopschutz", 2018a). Instead, the approach taken in Germany has been to assume that populations of this species are not stable (StA "Arten- und Biotopschutz", 2018a) since cold winter weather would result in high mortality of any released T. scripta (Geiger \& Waitzmann, 1996) and that successful reproduction would only be sporadic (Pieh \& Laufer, 2006)

The overall aim was to establish one of the first longterm monitoring programmes in Germany to investigate the population dynamics of $T$. scripta in an oxbow lake, the Altrhein of Kehl (Pieh \& Laufer, 2006; Laufer, 2007). This was 
undertaken to determine 1) If there is evidence of population decrease or increase, 2) Whether there is evidence of successful reproduction of this population, and 3 ) Whether there is evidence that additional individuals are released into the wild.

\section{METHODS}

\section{Study area and study period}

The study was conducted in the city of Kehl in BadenWürttemberg, Germany. Kehl is in the Upper Rhine Valley close to the French city of Strasbourg. Data were collected from the Altrhein of Kehl ( $\left.48^{\circ} 34^{\prime} 1.95^{\prime \prime} \mathrm{N}, 7^{\circ} 48^{\prime} 35.41^{\prime \prime} \mathrm{E}\right)$, which is an oxbow lake formed over 100 years ago from the River Rhine. It is $690 \mathrm{~m}$ long and between 25 and $80 \mathrm{~m}$ wide. The climate in Kehl is temperate, but the Upper Rhine Valley is one of the warmest areas of Germany. During the study period, the minimum temperature in winter was around $-12{ }^{\circ} \mathrm{C}(2016)$, and daily maximum temperatures in summer reached $40{ }^{\circ} \mathrm{C}$ in 2019 . Periods of permanent frost in winter were relatively short with 1 -2 weeks in the years 2016 - 2019, and no such period in 2020.

The study was implemented from May to July in the years 2016 to 2019 as part of a course that I gave at the Hector Kinderakademie Kehl, which provides additional education to highly gifted school children. In this course, I taught school children 8-9 years old about ecology and nature conservation. Due to the COVID-19 crisis, this course was cancelled in 2020. In this year, I used the opportunity to collect data on two sunny days in March (at this stage it was unsure whether later data collection would be possible) as well as during six afternoons in May and June. There was no indication that the March data differed from the later data (peak counts of individuals and species were recorded in May and June, the normal period of monitoring), and excluding these data would not have changed the results.

\section{Monitoring}

In the years 2016-2018, the population of exotic pond turtles was monitored on six afternoons, but on seven in 2019, and eight in 2020. At five locations along the eastern shore of the lake, that were previously determined to have a high abundance of pond turtles, observations were made using binoculars. In addition, any pond turtle observed between these locations was recorded. For every individual, the carapace length was estimated to be in one of the following categories: $5 \mathrm{~cm}, 10 \mathrm{~cm}, 20 \mathrm{~cm}$ or $30 \mathrm{~cm}$.

In 2016, only the number and size of observed pond turtles was noted. In this year it became evident that besides T. scripta several other species were present. In the following years, I took photographs of each of the individuals I observed from distances up to $30 \mathrm{~m}$. From 2017 to 2019, photographs were taken with a Panasonic HC-V380EG-K camcorder with 50x optical zoom, and in 2020 with a Nikon Coolpix P1000 Digital camera with $125 x$ optical zoom. Using characteristics of the carapace and especially the head, the genus, species and if possible sub-species of the photographed individuals was determined using a guide to the introduced turtles of Alsace (Pellerin, 2014). If the individual was in a position where it could not be identified it was scored as 'unknown genus'.

\section{Measurement of hatchlings}

I was contacted by teachers of a kindergarten near the lake when they found hatchlings of T. scripta. These were measured and then sent to an animal shelter in Munich (Germany) that specialises in reptiles (https://www.reptilienauffangstation. de/). I was also informed about sightings of large females that were believed to have left the lake to lay eggs.

\section{Data analysis}

Data have been expressed as peak counts, the maximum number of live individuals observed in one survey afternoon of a particular year. Where the peak count of all turtle species is given then this is the sum of peak counts of several species but potentially from observations made on different afternoons; similarly for the peak counts of individuals in different carapace size categories. Data were analysed using Spearman's rank correlation and Fisher's exact test in GraphPad Instat 3.05.

\section{RESULTS}

\section{Turtle numbers}

The annual total peak counts for all species increased continuously from 33 individuals in 2016 to 166 individuals in 2020 (Fig. 1), which resulted in a statistically significant correlation between year and peak count (Spearman rank correlation, $r_{s}=1.00, N=5, p=0.02$ ). These findings were contrary to the expectation that the population should decline each year due to cold weather mortality. The expected ratio for a decline each year would be 4:0, when this is compared with the observed ratio of $0: 4$ the difference is statistically significantly (Fisher's exact test, $p=0.03$ )

Over the years, increasing numbers of very small pond turtles with a carapace of not more than $5 \mathrm{~cm}$ were observed which was close to statistical significance (Spearman rank correlation, $r_{s}=0.90, N=5, p=0.08$, Fig. 2). All photographed pond turtles in this category were T. scripta. Additionally, the number of large pond turtles with a carapace of more than $20 \mathrm{~cm}$ increased over the years (Spearman rank correlation, $r_{s}=0.90, N=5, p=0.08$, Fig. 2). All pond turtles with a carapace of $30 \mathrm{~cm}$ belonged to one of the three following species: T. scripta, Pseudemys concinna, or Pseudemys nelsoni.

Altogether six different species were observed, with three subspecies of $T$. scripta (Table 1). Over the years the number of observed individuals of $T$. scripta seemed to increase (Fig. 3). The two species of Pseudemys and Graptemys pseudogeographica occurred in all years. A few individuals of Chrysemys picta and Mauremys sinensis were observed in all years except 2018 (Fig. 3).

\section{Breeding of Trachemys scripta}

Altogether, $12 T$. scripta hatchlings were found on land walking from a park towards the lake, more than $100 \mathrm{~m}$ away from the water. Eight were found in the period 12th to 22nd May 2019, one on 15th July 2019, one 19th May 2020, one on 17th June 2020 and one on 30th June 2020. Two of these were found dead on a bicycle path between the kindergarten and the lake, one died in the aqua-terrarium of the kindergarten. These dead individuals were disposed of by the kindergarten and not measured. The remaining 
Table 1. Annual peak counts for the turtle species observed in the Althrein of Kehl. Cloudy weather in 2018 made it difficult to determine the subspecies/species of both Trachemys and Pseudemys. Individuals for which the taxon could not be determined have been excluded.

\begin{tabular}{|l|cccc|}
\hline \multirow{2}{*}{$\begin{array}{l}\text { Genus, species, or } \\
\text { sub-species }\end{array}$} & \multicolumn{4}{|c|}{ Peak counts } \\
\cline { 2 - 5 } & $\mathbf{2 0 1 7}$ & $\mathbf{2 0 1 8}$ & $\mathbf{2 0 1 9}$ & $\mathbf{2 0 2 0}$ \\
\hline $\begin{array}{l}\text { Trachemys scripta } \\
\text { undetermined sub-species }\end{array}$ & 1 & 7 & 5 & 14 \\
T. s. elegans & 8 & 5 & 11 & 24 \\
T. s. scripta & 4 & 1 & 6 & 4 \\
T. s. troosti & 1 & 0 & 5 & 1 \\
Pseudemys sp & 3 & 12 & 2 & 1 \\
P. nelsoni & 3 & 1 & 1 & 7 \\
P. concinna & 10 & 3 & 7 & 26 \\
$\begin{array}{l}\text { Graptemys } \\
\text { pseudepgeographica }\end{array}$ & 6 & 3 & 4 & 7 \\
Mauremys sinensis & 1 & 0 & 1 & 2 \\
Chrysemys picta & 1 & 0 & 1 & 1 \\
TOTAL & $\mathbf{3 8}$ & $\mathbf{3 2}$ & $\mathbf{4 3}$ & $\mathbf{8 7}$ \\
\hline
\end{tabular}

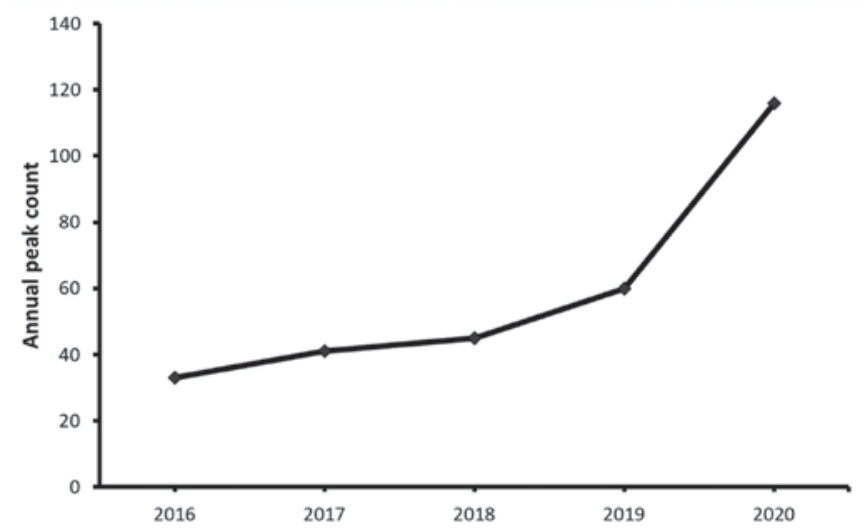

Figure 1. Annual peak count for all turtle species in the Althrein of Kehl combined (including individuals for which the taxon could not be identified and which are not shown in Table 1)

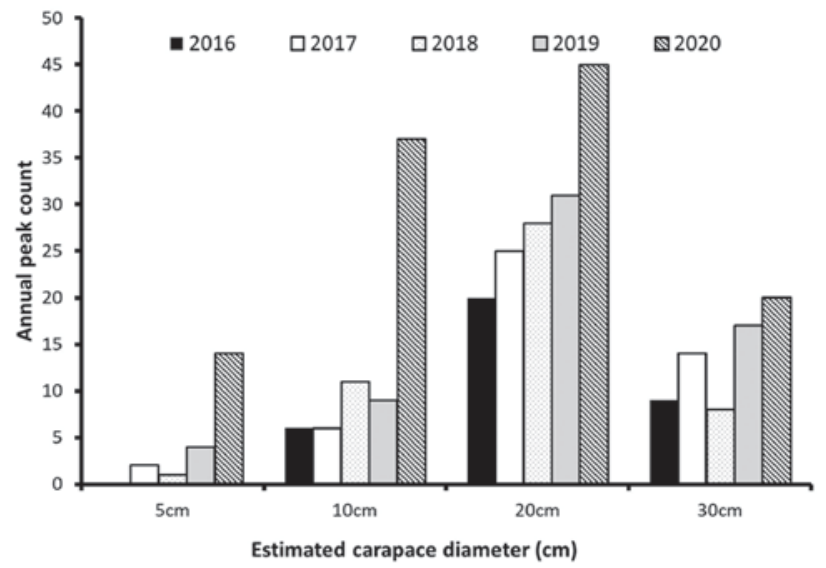

Figure 2. Annual peak counts for all turtle species observed in the Althrein of Kehl by carapace size category from 2016 to 2020

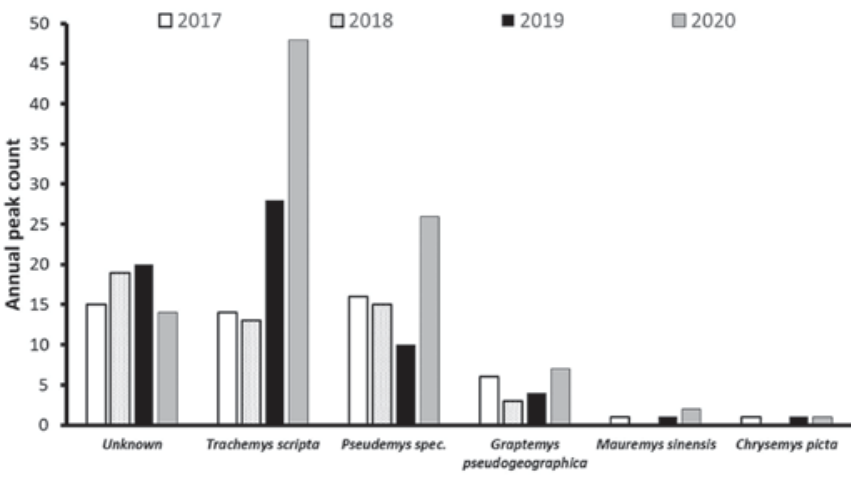

Figure 3. Annual peak counts of turtle species observed in the Althrein of Kehl from 2017 to 2020

Table 2. Measurements of nine hatchling T. scripta found at the Altrhein of Kehl (six from 2019 and three from in 2020) and of hatchlings from a natural population in the USA* for comparison

\begin{tabular}{|lccccc|}
\hline \multicolumn{1}{|c}{ Trait (mm or g) } & Mean & $\begin{array}{c}\text { Standard } \\
\text { deviation }\end{array}$ & Max. & Min. & $\begin{array}{c}\text { Data from } \\
\text { USA } \\
\text { (mean } \pm \text { SD)* }\end{array}$ \\
\hline Carapace length & 30.6 & 1.3 & 32.0 & 28.0 & $31.2+1.4$ \\
Carapace width & 30.4 & 1.3 & 32.0 & 29.0 & - \\
Carapace height & 15.8 & 1.5 & 19.0 & 13.5 & - \\
Plastron length & 28.7 & 2.0 & 31.0 & 26.0 & - \\
Plastron width & 22.3 & 2.1 & 27.0 & 19.5 & - \\
Body mass (g) & 6.5 & 0.7 & 7.8 & 5.3 & $6.9+0.8$ \\
\hline
\end{tabular}

*Data from Illinois, USA (Tucker, 2000)

nine individuals were kept and I was able to measure them, confirming that these were all hatchlings of T. scripta (Fig. 4, Table 2).

On 6th June 2019 a female $T$. scripta was caught at the kindergarten, with a body mass of $3064 \mathrm{~g}$ and a carapace length of $29 \mathrm{~cm}$. A female $T$. scripta elegans was seen laying eggs in the park behind the kindergarten on 15th June 2020. The clutch was excavated on 16th June, the top of which was $15 \mathrm{~cm}$ below ground. There were a total of 24 eggs with a length of $32.8+1.2 \mathrm{~mm}$ and a width of $23.9+0.7 \mathrm{~mm}$. The total clutch weighed $218 \mathrm{~g}$ which represented $9.1 \mathrm{~g}$ per egg.

\section{DISCUSSION}

In the current study I have shown that the population of pond turtles in an oxbow lake, the Altrhein of Kehl, comprises six exotic species with the invasive $T$. scripta being the most abundant. Contrary to predictions that in the cold climate of Germany populations would decline (Nehring, 2016; StA Arten-und Biotopschutz, 2018a; Geiger \& Waitzmann, 1996), population size seemed to have increased steadily over the five study years. This could be partly due to the release of more individuals into the wild as evidenced by 1) A high proportion of individuals being from genera other than Trachemys, indicating that species that are still available in pet shops are regularly released into the wild, and/or 2) The constant increase of the size category of carapace diameter $20 \mathrm{~cm}$ and $30 \mathrm{~cm}$ (Fig. 2), indicating that old individuals have been released, that might have been bought a long time ago 


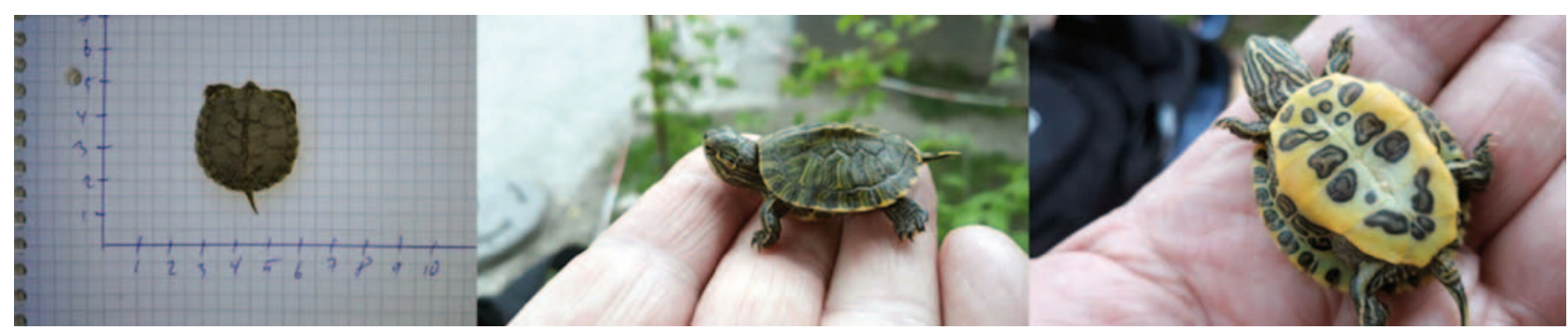

Figure 4. Three different Trachemys scripta elegans hatchlings found at the Altrhein of Kehl in May 2019. The scale on the left photo is in $\mathrm{cm}$.

and have become too big and as a consequence released by pet owners. Furthermore, the regular observation of hatchlings indicates that it cannot be assumed that the cold climate of Germany will prevent exotic pond turtles from breeding.

I had expected to observe mainly individuals from the three different subspecies of $T$. scripta in the lake and, based on previous reports, maybe some individuals of Graptemys pseudogeographica (Pieh \& Laufer, 2006; Laufer, 2007). It was a surprise to find a high exotic biodiversity with four commonly observed species (T. scripta, P. nelsoni, P. concinna, and G. pseudogeographica) and few individuals of the two species Mauremys sinensis and Chrysemys picta (Table 1). This high diversity is most likely a consequence of the trade ban on T. scripta, leading to a trade in other species (MacedaVeiga et al., 2019), which in turn have been released into the wild. Overall, the combined peak counts of all pond turtles increased consistently over the years (Fig. 1) which was due to an increased number of both small and large individuals (Fig. 2), especially of $T$. scripta (Fig. 3).

In southern France, clutch size of $T$. scripta varied between four and 11 eggs (Cadi et al., 2004), while here I found one clutch consisting of 24 eggs. I also observed one very large female of $3 \mathrm{~kg}$ that probably laid a clutch. Egg laying by itself is not evidence of successful reproduction since females will lay eggs whether or not they are fertilised and it is unknown whether fertilised eggs would develop successfully under the prevailing climatic conditions. In the current study, very small T. scripta were observed in four out of five years, making it likely that reproduction occurred repeatedly. The capture of hatchlings in both 2019 and 2020 showed that successful reproduction had occurred, especially as they were found in a park hundreds of meters away from the lake (any releases would have been into the lake). This is the second case of proven reproduction in Kehl with the first case having been in 2004 (Pieh \& Laufer, 2006). The absence of a report of reproduction in Kehl for the years 2005 to 2016 can be explained by a lack of monitoring during these years. In 2019, the seven hatchlings found in Kehl within 10 days in May plus the single hatchling found in July indicates that these might be from two or three different clutches. The hatchlings must likely originate from clutches laid in summer 2018, and probably overwintered in a nest burrow as suggested by Pieh \& Laufer (2006). Reproduction might have been possible due to the recently mild winters, as it is known that eggs easily survive temperatures as low as $-4{ }^{\circ} \mathrm{C}$ in the soil (Tucker \& Packard, 1998), which would represent much colder air temperatures. For example, in the winter 2019/2020, frost was uncommon in Kehl. In its northern range, mean summer temperatures are around $23{ }^{\circ} \mathrm{C}$ (June to August, embryonic period) and winter temperatures $6-8^{\circ} \mathrm{C}$ (September to April, posthatching dormancy) (Willette, Tucker \& Janzen, 2005). While mean summer temperatures in Kehl are clearly colder $\left(18.7^{\circ} \mathrm{C}\right)$, winters are within the reported range $\left(7.9^{\circ} \mathrm{C}\right)$ (data from the closest weather station at Entzheim, France). As such, the climate in Kehl does not preclude successful reproduction.

The size and mass of both hatchlings and eggs was similar to those reported from their natural habitat (Tucker, 2000) as well as other populations in Europe (Perez-Santigosa, DíazPaniagua \& Hidalgo-Vila ,2008). The mean egg mass reported here was $9.1 \mathrm{~g}$ compared to $10.5 \mathrm{~g}$ in Illinois and $9.4 \mathrm{~g}$ in Spain (Perez-Santigosa, Díaz-Paniagua \& Hidalgo-Vila, 2008), while hatchling mass in the current study was $6.5+0.7 \mathrm{~g}$ compared to $6.8+0.8 \mathrm{~g}$ in Illinois (Tucker, 2000) and $6.7+1.0 \mathrm{~g}$ in Spain (Perez-Santigosa, Díaz-Paniagua \& Hidalgo-Vila, 2008). As such, data from both eggs and hatchlings do not indicate constraints on reproduction of $T$. scripta in Kehl, Germany.

Reproduction of released T. scripta has been reported in southern Europe (Cadi et al., 2004; Perez-Santigosa, DíazPaniagua \& Hidalgo-Vila, 2008; Sperone et al., 2010; Sancho \& Lacomba, 2016; Foglini \& Salvi, 2017), but also in a part of Croatia with a continental climate (Koren et al., 2018), as well as in central Europe in Slovenia (Standfuss et al., 2016). The regular reproduction of $T$. scripta reported here for Germany adds to previous records of successful reproduction in temperate climates.

Even though successful reproduction of T. scripta in Europe has been observed, it has been argued that this will not make the species invasive, as sex determination in this species is temperature dependent (Geiger \& Waitzmann, 1996). The sex ratio of clutches is influenced by soil temperature, and at low temperatures all hatchlings are male while both sexes can be produced from incubation temperatures between 28.3 and $30.6{ }^{\circ} \mathrm{C}$ (Cadi et al., 2004). Female hatchlings have been observed both in Spain (Perez-Santigosa, Díaz-Paniagua \& Hidalgo-Vila, 2008) and in southern France (Cadi et al., 2004). So far, no soil temperature data are available for Kehl, but air temperatures above $33^{\circ} \mathrm{C}$ during the day and above $20^{\circ} \mathrm{C}$ at night are common in summer and often occur for periods of two weeks or more. The hatchlings captured in the current study were too small to be sexed. Climate warming will make it more likely that females will hatch in the future.

To make management decisions for the long-lived, slow 
reproducing $T$. scripta, it is essential to estimate how their populations will develop for several decades. Most T. scripta sold in pet shops are female, as breeders in the USA used high temperatures for faster hatching, and higher temperatures induce a female biased sex-ratio (Prevot et al., 2007). The combination of a potential female biased sex ratio of released sliders (Prevot et al., 2007) and a male biased sex ratio of hatchlings could cause an increased population growth in the medium-term (5-20 years), as more females will lay fertilised eggs. An overall increase in the number of hatchlings together with rising temperatures due to global warming makes it more likely that female hatchlings will occur in the coming decades. Heat waves, such as the one experienced in Kehl in 2019 when temperatures reached $40{ }^{\circ} \mathrm{C}$, will increase the number of female hatchlings (Breitenbach et al., 2020). This scenario makes it likely that the $T$. scripta populations in Kehl are now fully entrenched and that other populations will become established in other areas of the Upper Rhine Valley. Pseudemys nelsoni, P. concinna, G. pseudogeographica and $M$. sinensis have a low risk of becoming invasive in Europe (Kopecký, Kalous \& Patoka, 2013; Masin, 2014). In contrast, T. scripta is generally regarded as being invasive, as in many countries it can survive, breed, and colonise additional habitats with negative impact on the native biodiversity (Lowe et al., 2000). However, detailed studies on its effect on the native fauna and flora are rare. In France, young $T$. scripta are omnivores, eating invertebrates, amphibians and fish, while older individuals have a more herbivorous diet (Prevot et al., 2007). They have been observed to disturb the nests of water birds when searching for basking spots (Laufer, 2007). They might have a negative impact on the endangered native European pond turtles (Emys orbicularis) by trying to mate with them (Jablonski et al., 2017) and by competing for basking spots (Cadi \& Joly, 2003). In Kehl, the oxbow lake is not known as an important site for native biodiversity, but there are ecologically important areas close by (less than 1 $\mathrm{km})$, especially the Rhine floodplains. Increasing population size in the lake increases the risk that these habitats would be colonised. Further, T. scripta have also been observed next to the Kehler nature reserve Sundheimer Grund (less than 3 km from the Altrhein), an ecologically important and vulnerable habitat (Schradin, personal observation).

\section{Implications for German and European legislation}

The regulation (EU) No 1143/2014 demands that all member states should take action against invasive species (European Parliament, 2014) including T. scripta (European Commission, 2016). After the trading ban in 2006 it was expected that the release of $T$. scripta into the wild would decline in Germany. But the current study, undertaken 14 years later, does not support this assumption. In Germany, it has been believed that the only action needed was to advise the public not to release exotic pond turtles into the wild since it was too cold for the released individuals to survive for long periods or to reproduce (Geiger \& Waitzmann, 1996; Pieh \& Laufer, 2006; Laufer, 2007; Nehring, 2016). Thus, populations in Germany are officially believed to be unstable (Nehring, 2016; StA "Arten- und Biotopschutz", 2018b), which has influenced the national action plan (StA "Arten- und Biotopschutz", 2018a). In light of the facts uncovered by the current study that population size is not decreasing, there is no indication of high mortality and successful reproduction occurs more regularly than previously believed, the management plan in Germany should be reconsidered.

The results presented here add to several other studies indicating that $T$. scripta has the potential to become invasive in western, middle and central Europe (Mačát \& Jablonski, 2016; Standfuss et al., 2016; Koren et al., 2018). Thus, action plans to avoid an invasion might not only have to be changed for Germany, but for many other European countries. For France, removal of sliders from wetlands has been suggested (Cadi et al., 2004), and this has been done in Spain (Sancho \& Lacomba, 2016). While the invasion is slower in colder regions, the fact that the exotic populations there do not decline but reproduce and increase should be of concern. Additional actions are required; good examples have been suggested by (Teillac-Deschamps et al., 2009). An obvious need is public education with a focus on pet owners such as a social media campaign targeting Facebook groups of owners of exotic pond turtles. Education is also needed for law enforcement (police, order enforcement offices, wardens), whose focus is often the poor pet owner who has 'lost' a pond turtle instead of the criminal that released it. Police statements to the local news outlets could then emphasise the unlawfulness of the release of exotic animals. Local order enforcement officers could check owners of exotic pond turtles to ensure no breeding takes place and animals kept in the garden cannot escape. An active search for advertisements posted by people selling hatchlings of exotic pond turtles followed by legal action would be useful. Alternatives to release should be made available which means that more financial state support is needed for animal shelters to create more space for unwanted pond turtles.

Other important actions would be 1) Destruction of clutches; 2) Removal of large females from the population when they are found on land before / after laying clutches, and 3) Active removal of released exotic pond turtles, especially from ecologically valuable waters. For this, local resources would be needed, especially staff being able to perform and coordinate these actions. Collaboration between nature conservation officers of the local communities with nature conservation groups, hunters, and local fishery association are needed for this. Last but not least, the increased release of other exotic pond turtle species leads to the question which of these species should also be banned from trade, and how the trade is regulated to ensure that individuals will not be released. Individual marking (transponders) and registration of exotic pond turtles to allow previous owner to be identified may be an effective option.

\section{Going forward}

The population of exotic pond turtles at the Althrein of Kehl has not decreased since the ban of the trade of $T$. scripta in the European Union. On the contrary, the diversity of species being released has increased. In addition, the population size of $T$. scripta is increasing, and there is no indication of high mortality due to cold winters. In contrast, there seems to be regular successful reproduction in summer. This might 
lead to a more balanced sex ratio in the future and as such a further increase in reproduction and population size. It is now important to measure soil temperatures, to determine the sex ratio of hatchlings, and to combine this with climate predictions for the next 30 years. Furthermore, ecologically important wetlands close to waters into which pond sliders have been released must be monitored and actions must be taken to remove pond sliders from these areas before they can establish themselves there. The further growth of existing neobiotic pond slider populations must be stopped. The current action plan in Germany for T. scripta will have to change if an invasion is to be avoided. Other west and central European countries might have to apply similar action plans.

\section{ACKNOWLEDGEMENTS}

This project was funded by the CNRS. The project was done as part of a course I do at the Hector Kinderakademie in Kehl, teaching 8-9 year old children about animal behaviour, population biology, animal welfare and nature conservation. I am very thankful to the Hector Kinderakademie in Kehl for their support. I am very grateful to the teachers of the Kindergarten St. Josef for informing me about so many turtle sightings. I am thankful to members of the Facebook group "Wasserschildkröten" which assisted me in identifying species from photographs, especially to N. Ziegenhagen, who runs an animal shelter for exotic pond turtles. I would also like to thank the city of Kehl (Dr. A.-M. Amui-Vedel, Bereich Stadtplanung/Umwelt) and the Regierungspräsidium Freiburg (S. Person, M. Bickel) for their support for this study. Comments by Rick Hodges, Richard Griffiths and one anonymous referee significantly improved the manuscript.

\section{REFERENCES}

Böhm, S. (2013). Records of invasive Trachemys scripta elegans (WiEd-NEuWiEd, 1839), in cenotes of the Yucatán Peninsula, Mexico. Herpetozoa 26: 98-100.

Breitenbach, A.T., Carter, A.W., Paitz, R.T. \& Bowden, R.M. (2020). Using naturalistic incubation temperatures to demonstrate how variation in the timing and continuity of heat wave exposure influences phenotype. Proceedings of the Royal Society B: Biological Sciences 287: 20200992.

Cadi, A., Delmas, V., Prevot-Julliard, A.C., Joly, P., Pieau, C. \& Girondot, M. (2004). Successful reproduction of the introduced slider turtle (Trachemys scripta elegans) in the South of France. Aquatic Conservation-Marine and Freshwater Ecosystems 14: 237-246.

Cadi, A. \& Joly, P. (2003). Competition for basking places between the endangered European pond turtle (Emys orbicularis galloitalica) and the introduced red-eared slider (Trachemys scripta elegans). Canadian Journal of Zoology-Revue Canadienne de Zoologie 81: 1392-1398.

European Commission (2016). Implementing Regulation (EU) 2016/1141 of 13 July 2016 adopting a list of invasive alien species of Union concern pursuant to Regulation (EU) No $1143 / 2014$ of the European Parliament and of the Council. Official Journal of the European Union L 189/4.

European Parliament (2014). Regulation (EU) No 1143/2014
On the prevention and management of the introduction and spread of invasive alien species. European Parliament, Council of the European Union. Official Journal of the European Union L 317/35.

Foglini, C. \& Salvi, R. (2017). Non-native turtles in a peri-urban park in northern Milan (Lombardy, Italy): species diversity and population structure. Acta Herpetologica 12: 151156

Geiger, A. \& Waitzmann, M. (1996). Überlebensfähigkeit allochthoner Amphibien und Reptilien in Deutschland - Konsequenzen für den Artenschutz. In Gebietsfremde Tierarten. Auswirkungen auf einheimische Arten, Lebensgemeinschaften und Biotope. Situationsanalyse, Gebhardt, H., Kinzelbach, R. \& Schmidt-Fischer S. (Eds). ECO Med Verlag.

Jablonski, D., Mrocek, J., Grula, D. \& Christophoryová, J. (2017). Attempting courtship between Emys orbicularis and Trachemys scripta (Testudines: Emydidae). Herpetology Notes 10: 123-126.

Kopecký, O., Kalous, L. \& Patoka, J. (2013). Establishment risk from pet-trade freshwater turtles in the European Union. Knowledge and Management of Aquatic Ecosystems 410: 02p01-02p11.

Koren, T., Stih, A., Buric, I., Koller, K., Laus, B. \& Zadravec, M. (2018). The current distribution of pond slider Trachemys scripta (Reptilia: Emydidae) in Croatia. Natura Slovenia 20: 33-34.

Laufer, H. (2007). Buchstaben-Schmuckschildkröte Trachemys scripta (Schoepff). Die Amphibien und Reptilien BadenWürttembergs, Laufer, H., Fritz, K. \& Sowig, P. (Eds) , pp. 525-536. Ulmer-Verlag, Stuttgart.

Lowe, S., Browne, M., Boudjelas, S. \& De Poorter, M. (2000). 100 of the World's Worst Invasive Alien Species. A selection from the Global Invasive Species Database. pp 12. http://www.issg.org/pdf/publications/worst_100/ english_100_worst.pdf (accessed Oct 2020)

Mačát, Z. \& Jablonski, D. (2016). Good invasion ability is not enough: Predation on the pond slider (Trachemys scripta) by the wels catfish (Silurus glanis) in the Czech Republic. Herpetological Bulletin 135: 38-39.

Maceda-Veiga, A., Escribano-Alacid, J., Martínez-Silvestre, A., Verdaguer, I. \& Mac Nally, R. (2019). What's next? The release of exotic pets continues virtually unabated 7 years after enforcement of new legislation for managing invasive species. Biological Invasions 21: 2933-2947.

Masin, S. (2014). Risk of invasion by frequently traded freshwater turtles. Biological Invasions 16: 217-231.

Mo, M. (2019). Possible records of yellow-bellied sliders (Trachemys scripta scripta) or river cooters (Pseudemys concinna) in Hong Kong. IRCF Reptiles and Amphibians 26: 51-53.

Nehring, S. (2016). Die invasiven gebietsfremden Arten der ersten Unionsliste der EU-Verordnung Nr. 1143/2014. Bundesamt für Naturschutz, Bonn.

Pellerin, E. (2014). Les tortues introduites. Bufo contacts 15.

Perez-Santigosa, N., Díaz-Paniagua, C. \& Hidalgo-Vila, J. (2008). The reproductive ecology of exotic Trachemys scripta elegans in an invaded area of southern Europe. Aquatic Conservation: Marine and Freshwater Ecosystems 
18: 1302-1310.

Pieh,A.\&Laufer,H. (2006). DieRotwangen-Schmuckschildkröte (Trachemys scripta elegans) in Baden-Württemberg - mit Hinweis auf eine Reproduktion im Freiland. Zeitschrift für Feldherpetologie 13: 225-234.

Prevot, A.-C., Gousset, E., Archinard, C., Cadi, A. \& Girondot, M. (2007). Pets and invasion risks: Is the slider turtle strictly carnivorous? Amphibia-Reptilia 28: 139-143.

Sancho, V. \& Lacomba, I. (2016). Expansion of Trachemys scripta in the Valencian Community (Eastern Spain). International Symposium on Freshwater Turtle Conservation: 41-49.

Schradin, C. \& Hayes, L.D. (2017). A synopsis of long-term field studies of mammals: achievements, future directions, and some advice. Journal of Mammalogy 98: 670-677.

Sperone, E., Crescente, A., Brunelli, E., Paolillo, G. \& Tripepi, S. (2010). Sightings and successful reproduction of allochthonous reptiles in Calabria. Acta Herpetologica 5: 265-273.

StA "Arten- und Biotopschutz" (2018a). BuchstabenSchmuckschildkröte-Management- und Maßnahmenblatt zu VO (EU) Nr. 1143/2014. LANa.

StA "Arten- und Biotopschutz" (2018b). Länderspezifische Anlage zur Verbreitung- Management- und Maßnahmenblatt zu VO (EU) Nr. 1143/2014. LANa.
Standfuss, B., Lipovšek, G., Fritz, U. \& Vamberger, M. (2016). Threat or fiction: is the pond slider (Trachemys scripta) really invasive in Central Europe? A case study from Slovenia. Conservation Genetics 17: 557-563.

Teillac-Deschamps, P., Lorrilliere, R., Servais, V., Delmas, V., Cadi, A. \& Prevot, A.-C. (2009). Management strategies in urban green spaces: Models based on an introduced exotic pet turtle. Biological Conservation 142: 2258-2269.

Tucker, J.K. (2000). Annual variation in hatchling size in the red-eared slider turtle (Trachemys scripta elegans). Herpetologica 56: 8-13.

Tucker, J.K. \& Packard, G.C. (1998). Overwinter survival by hatchling sliders (Trachemys scripta) in West-Central Illinois. Journal of Herpetology 32: 431-434.

Willette, D.A.S., Tucker, J.K. \& Janzen, F.J. (2005. Linking climate and physiology at the population level for a key life-history stage of turtles. Canadian Journal of Zoology 83: 845-850.

Wilson, J., Dormontt, E., Prentis, P., Lowe, A. \& Richardson, D. (2009). Something in the way you move: dispersal pathways affect invasion success. Trends in Ecology \& Evolution 24: 136-144.

Accepted: 17 October 2020 